UDC 339.9

DOI 10.33111/iep.eng.2021.34.04

\title{
Asymmetry of External Effects of the Budget Balance of the Largest Eurozone Countries as an Obstacle to Fiscal Policy Coordination
}

\author{
ROMAN KOPYCH ${ }^{1}$, \\ VIKTOR SHEVCHUK ${ }^{2}$
}

\begin{abstract}
The paper analyses the external effects of the fiscal policy of the Eurozone and the two largest countries (Germany, France) vs the countries of the European frontier area. Based on the corresponding VAR-models with three variables (budget balance of the largest Eurozone countries, real exchange rate (RER), cyclical behaviour of GDP) according to quarterly data of 2002-2019 it was found that improvement of the budget balance of Eurozone countries in Central and Eastern Europe (CEE) leads to an increase in RER (this is a short-term effect at a floating exchange rate, for the countries with a fixed exchange rate - this is a quite long-term effect), while the response of relative prices to the Eurozone budget surplus is much weaker in Southern Europe (only in Spain there is an option of RER reduction). The price response to the improvement of the budget balance in Germany and France is quite diversified in terms of the countries studied. The impact on GDP changes is much more stable in terms of individual countries. The improvement in the budget balances of Germany, France and the Eurozone has a positive effect on the GDP cyclical changes in CEE countries (this may be a result of reduced business profitability in the countries initiating fiscal austerity policy and relocation of industrial enterprises to reduce production costs), while the contrary trends are typical for "problematic" countries of Southern Europe (Greece, Spain, Portugal). The relevant structure feature highlights the difficulties of coordinating fiscal policy within such a heterogeneous integration entity as the European Union, but at the same time emphasizes the need to harmonize fiscal decisions through respective institutional tools at the national and supranational levels. Among these tools could be the introduction of a fiscal policy rule that considers the external effects of the fiscal policy of the largest Eurozone countries. In combination with other institutional tools for adjusting fiscal policy, this should facilitate not only countercyclical stabilization policy but also several structure problems, commonly referred to as obstacles to the effective integration approach (low labour and capital fluidity, limited price and wage flexibility, insufficient efficiency of the stabilization function of both the common monetary policy of the Eurozone countries and the policy of flexible exchange rate introduction in other countries).
\end{abstract}

KEY WORDS: external effects of fiscal policy, cyclical changes in GDP, real exchange rate, Eurozone, countries of European frontier area.

\section{Introduction}

It may be said without exaggeration that the debt crisis in Greece (2010-2013) highlighted both the shortcomings of insufficient fiscal policy adjustment in the EU and the benefits of coordinated actions to overcome

* This article was translated from its original in Ukrainian.

${ }^{1}$ Kopych Roman Ivanovych - Doctor of Economics, Associate Professor of the Department of International Economic Analysis and Finance, Ivan Franko National University of Lviv. Sphere of scientific interest: fiscal policy in integration formations, stabilization function of fiscal policy in transformational economies, features of fiscal devaluation. E-mail: kopych_r@bigmir.net.

2 Shevchuk Viktor Oleksiiovych - Doctor of Economics, Professor, Professor of the Department of International Economic Relations, Lviv University of Trade and Economics. Sphere of scientific interest: balance of payments, exchange rate policy, open economy models. E-mail: shevch@lute.lviv.ua

IEP, No. 34 (2021), pp. 70-90

(c) Roman Kopych, Viktor Shevchuk, 2021 «All rights reserved»

ISSN 1811-9832/2021/No. 1 (34) 
the crisis $^{3}$. As noted in a review of six monographs, overcoming the 20102013 Eurozone debt crisis was due to the strength of and trust of supranational institutions rather than German or German-French leadership ${ }^{4}$. The contrasting improvement in the budget balances in Germany (to a lesser extent in France and the Netherlands) these years, which has been called fiscal austerity policy, is often seen as one of the reasons for the deepening debt crisis of Southern Europe. In addition to a number of conventional arguments (better allocation of resources, higher volumes of mutual trade, smaller amplitude of payment imbalances), in favour of fiscal policy coordination, there are significant external effects from changes in the budget balances of the largest Eurozone countries ${ }^{5}$. On the other hand, information asymmetries and national preferences, which do not show weakening patterns in the post-crisis economic environment, have the opposite effect ${ }^{6}$.

The reasons for fiscal policy coordination accelerate the national governments to expand fiscal policy during the economic boom, which limits the opportunities for countercyclical increases in the budget gap in case of recession ${ }^{7}$. Often, in high-level integration, the consequences of big budget gap in some countries must be offset by excessive fiscal savings in other countries as happened in the EU within 2010-2013. Incentive for fiscal policy coordination is strengthened by: low labour and capital fluidity, limited price and wages flexibility, insufficient efficiency of the stabilization function of both the common monetary policy of the Eurozone countries and the policy of flexible exchange rate introduction in other countries) ${ }^{8}$.

As common monetary policy tools and self-regulating fiscal decisions (at the level of individual countries) are not enough for Eurozone countries to support effective stabilization policy, the fiscal policy coordination through

\footnotetext{
${ }^{3}$ The first attempt to coordinate fiscal policy in the EU was the Stability and Growth Pact (SGP) adopted in June 1997, although the record on the coordination of economic policies of the EU to ensure stable economic growth contains Art. 99 European Community Treaty. Werner's plan (1970) provided for the future European Central Bank (ECB) to be supplemented by a specialized institution for the coordination of fiscal policy. However, Delors' plan (1989) later ruled out this possibility due to possible obstacles to the ECB's activities (this position was supported by Germany).

4 Sadeh T. How did the Euro Area survive the crisis? // West European Politics. — 2019. — Vol. 42. — No. 1. - P. 201-226.

5 Hebous S., Zimmermann T. Estimating the Effects of Coordinated Fiscal Actions in the Euro Area // European Economic Review. - 2013. - Vol. 58. - No. 2. - P. 110-121.

6 Wyplosz C. The six flaws of the Eurozone // Economic Policy. — 2016. — Vol. 31. - No. 87. P. 559-606

${ }^{7}$ Lambertini L., Rovelli R. Optimal Fiscal Stabilization Policy with Credible Central Bank Independence // Quaderni- Working Paper DSE No. 460. - Bologna: Universita' di Bologna, 2002. - 13 p.

8 Acocella N.. Di Bartolomeo G.. Tirelli P. Monetary conservatism and fiscal coordination in a monetary union // Economics Letters. - 2007. - Vol 94 - No. 1. - P. 56-63; Beetsma R. Debrun X., Klaassen F. Is Fiscal Policy Coordination in EMU Desirable? // IMF Working Paper No. WP/01/178. - Washington: International Monetary Fund, 2001. - 32 p.; Canzoneri M., Cumby R., Diba B. The need for international policy coordination: what's old, what's new, what's yet to come? // Journal of International Economics. — 2005. — Vol. 66. — No. 2. - P. 363-384.
} 
supranational rules and regulations is needed to reduce interest rates and limit excessive public debt, which usually introduce unnecessary stress in the banking system and the deterioration of competitiveness of European countries $^{9}$. For example, IMF experts suggest strengthening incentives for responsible fiscal policy, the use of temporary transfers from the EU joint budget, strengthening banking supervision, limited floating of bonds at the EU level ${ }^{10}$.

On a bigger analytical scale, obstacles to fiscal policy coordination prevent identifying the best indicators of budget gap and public debt in economies with an aging population and predicting the further fiscal indicators ${ }^{11}$. The Eurozone example states that the SGP criteria are insufficiently substantiated and not supported by strong conformance procedures ${ }^{12}$. In general, instead of cancellation of macroeconomic shocks, independent fiscal policy might become an additional source of such shocks. At first glance, the spread of macroeconomic shocks is a reason in favour of fiscal policy coordination, but the growing correlation of fiscal shocks for individual countries (it might be due to greater coordination) denies the feasibility of such approach ${ }^{13}$. In the absence of fiscal policy coordination, risk diversification introduces an advantage, as the total risk decreases due to the lower correlation between the risks of individual countries.

In our opinion, the possible unbalance of the external effects of the fiscal policy of the largest Eurozone countries will lead to significant difficulties. Against such background, a conflict of interest arises when the fiscal policy of Germany or France is able to prevent the renewal of economic growth in some countries of the European frontier area, while for other countries the impact will be favourable.

The article is aimed to study the impact of the budget balances of Germany and France and the Eurozone on two groups of countries CEE and Southern Europe, which is of interest to identify instrumental tools for coordinating fiscal policy and assessing its stabilizing function in integration. First, we arranged the study results against the external effects of fiscal policy in the EU, and then presented the research pattern, obtained observational findings and proposals for economic policy.

9 Begg I., Hodson D., Maher I. Economic policy coordination in the European Union // National Institute Economic Review. - 2003. - Vol. 183. - No. 1. - P. 66-77.

10 Allard C., Brooks P. K., Bluedorn J. C., Bornhorst F., Christopherson K. Ohnsorge F. Poghosyan T. Toward a Fiscal Union for the Euro Area // IMF Staff Discussion Note No. 13/09. - Washington: IMF, 2013. — 28 p.

${ }_{11}$ Auerbach A. Budget Rules and Fiscal Policy: Ten Lessons from Theory and Evidence // German Economic Review. - 2014. - Vol. 15. - No. 1. - P. 84-99.

12 Wyplosz C. The six flaws of the Eurozone // Economic Policy. - 2016. - Vol. 31. - No. 87. P. 559-606.

${ }_{13}$ Belke A., Gros D. On the benefits of fiscal policy coordination in a currency union: a note // Empirica. — 2009 — Vol. 36. — No. 1. - P. 45-49. 


\section{Review of current research on the external effects of fiscal policy}

External effects are critical to the fiscal policy coordination, as the impact of the fiscal policy of the largest EU countries may differ in terms of individual countries on the European frontier area, and macroeconomic shocks may be asymmetric ${ }^{14}$. Normally, countries differ in the speed of response to changes in inflation, which is managed at the Eurozone level. It is important that the fiscal policy of the Eurozone largest countries fixes the long-term interest rate of the EU countries and can introduces an additional "trust anchor".

The fiscal policy of one of the largest European countries (Germany, France, Italy) is expected to affect the economic growth of the European frontier area (CEE countries, Southern and Northern Europe) through several tools: 1) (increase in aggregate demand involves trading partners), 2) relative prices (rising prices and wages increases the positive impact of the income effect), 3) capital flows (this is due to changes in interest rates), 4) risk $^{15}$. In a monetary union, the risk premium may be extended to other countries, primarily for the purpose of implementing coordinated financial assistance programs.

For historical reasons, the first attempt to analyse the comparative impact of external effects of fiscal policy was implemented through the well-known Mandel-Fleming model, which in case of increasing budget deficits abroad maintains an expansionary effect of income, which is stronger at a fixed exchange rate. However, for a floating exchange rate, you can get a favourable price effect from the devaluation of the currency. An increase in interest rates abroad is expected to increase the devaluation range due to capital outflows, but at the same time, the effect of income weakens. For a fixed exchange rate, capital outflows have the opposite restrictive effect by monetary contraction.

One of the first attempts to move away from the Mandel-Fleming model was the Redux model ${ }^{16}$. As the increase in government expenditures involves both domestic and foreign goods, production yield is growing both in the initiating country and abroad. If the increase in government expenditures is temporary, the impact on output abroad (external effect) is

\footnotetext{
${ }^{14}$ The external effects of fiscal policy are a necessary element of fiscal policy harmonization as a process of convergence of fiscal decisions, considering the national characteristics of the participating countries. If earlier this was considered primarily in the context of tax competition and the coordinated use of expenditures on joint programs, today the emphasis has shifted towards the external effects, related payment imbalances and the stabilizing function of fiscal policy in general.

15 Veld J. Fiscal Consolidations and Spillovers in the Euro Area Periphery and Core // EC Economic Papers No. 506. - Brussels: European Commission, 2013. -28 p.

16 Obstfeld M., Rogoff K. Exchange Rate Dynamics Redux // Journal of Political Economy. — 1995. - Vol. 103. - No. 3. - P. 624-660.
} 
favourable, as the direct income effect outweighs the loss from the exchange adjustment. However, in case of permanent increase in government expenditures, the price effect dominates, so that income abroad decreases in the short run.

One of the popular neo-Keynesian DSGE models by K. Erceg and J. Lindй said that fiscal consolidation based on reduced government expenditures leads to a smaller decline in output in the long run compared to tax revenues increase in the short run ${ }^{17}$. N. Gadatsch, K. Hauzenberger and N. Stдhler in the model with so-called "realist" consumers found that $1 \%$ GDP increase in government expenditures in Germany can boost the economic growth in this country by $1.2 \%$, but growth in other Eurozone countries is only $0,12 \%{ }^{18}$. Instead, fiscal consolidation measures lead to a slowdown in German GDP by $0.8 \%$ and in the Eurozone by $1.2 \%$. In similar theoretical terms, A. Barbier-Goshar, T. Betty, and D. Dian found that a temporary increase in income abroad could be resulted from an increase in government procurement, tax reduction - VAT and income tax, and a reduction in pension contributions ${ }^{19}$. A steady increase in income can be resulted from an increase in public investment, while consumer expenditures maintain restrictive influence.

In general, in neo-Keynesian DSGE models, the results of public investment are similar to a technological shock: reduced labour costs and increased labour efficiency. At the same time, lower inflation introduces the preconditions for lower interest rates and increased private consumption. The resulting decline in production costs, slower inflation and lower interest rates accelerate aggregate demand. Abroad income is growing despite deteriorating price ratios in foreign trade.

The neoclassical RBC models do not deny the encouragement of peripheral countries through higher government expenditures or tax cuts in leading European countries, but they depend on the patterns of fiscal policy. D. Corsetti, A. Meier and G. Mbller found that the increase in government expenditures has a temporary accelerating effect on the initiating country, but is affected by the economic downturn abroad ${ }^{20}$. The external effects of fiscal policy depend on the price elasticity of foreign trade, the size of country, the degree of openness, the state of the financial market, as well as the features of fiscal consolidation in the medium term. In closed economies, private consumption and investment are declining, as

17 Erceg C., Lindé J. Fiscal consolidation in a currency union: spending cuts vs. tax hikes // Journal of Economic Dynamics \& Control. — 2013. - Vol. 37. - No. 2. - P. 422-446.

18 Gadatsch N., Hauzenberger K., Stähler N. German and the rest of euro area fiscal policy during the crisis // DB Discussion Paper No. 05/2015. - Frankfurt: Deutsche Bundesbank, 2015. - 50 p.

19 Barbier-Gauchard A., Betti T., Diana G. Spillover effects in a monetary union: Why fiscal policy instruments matter // Working paper No. 2015-01. - Strasbourg: Université de Strasbourg, 2015. — 37 p.

20 Corsetti G., Meier A., Müller G. Cross-Border Spillovers from Fiscal Stimulus // International Journal of Central Banking. - 2010. - Vol. 6. - No. 1. - P. 5-37. 
attributive to neoclassical models, but open economy promotes private consumption and investment, which more than offsets the effect of higher import demand. After an increase in government expenditures and a deterioration in the budget balance, it is most likely to expect RER increase and deterioration in the trade balance. There was got for ten OECD countries that government expenditures accelerate income (the multiplier is 0.5 ), but reduce private consumption and investment in a rather closed economy ${ }^{21}$. The trade balance is slightly worsening, primarily due to higher RER in the country that initiated the fiscal shock.

The increase in income abroad after the increase in government expenditures in a large open economy is introduced by the neoclassical model of $\mathrm{M}$. Baxter ${ }^{22}$. Higher government expenditures due to the negative welfare effect "displaces" private consumption. Demand for investment is growing, but the resulting increase in interest rates deepens the stagnation of private consumption. Abroad, the situation is the following: investment is growing and private consumption is declining. In the initiating country, declining public sector savings and increased investment are becoming instrumental factors of the worsening trade balance.

Long-term interest rate expectations, which depend on inflation, can influence, too ${ }^{23}$. If fiscal consolidation is accompanied by lower inflation expectations (this is what the well-known Taylor rule suggests), the longterm interest rate is expected to be reduced, which normally shifts to a reduction in the short-term interest rate. The resultant increase in income has a positive impact on trading partners due to increased demand for imported goods.

In general, the adjustment of neo-Keynesian and neoclassical models shows that the external effect of changes in fiscal policy is relatively small, although the expansionary effect may be boosted by low interest rates ${ }^{24}$. No less contradictory are the theoretical predictions of several other models of open economy.

For example, А. Вйnassy-Quйrй, using the Phillips curve model, showed that a budget deficit introduces a positive external effect if the central bank prevents an increase in interest rates $^{25}$. Otherwise, the external effects

21 Corsetti G., Müller G. Twin deficits, openness and the business cycle // Journal of European Economic Association. - 2008. - Vol. 6. - No. 2-3. - P. 404-413.

22 Baxter M. International trade and business cycles // Handbook of International Economics / G. M. Grossman and K. Rogoff (eds.). - Amsterdam: North-Holland, 1995. — P. 1801-1868.

23 Canova F., Ciccarelli N., Dallari P. Spillover of fiscal shocks in the Euro Area. - Frankfurt: European Central Bank, 2013. $-52 \mathrm{p}$.

24 Alcidi C., Määttänen N., Thirion G. Cross-Country Spillover Effects and Fiscal Policy Coordination in EMU // FIRSTRUN - Fiscal Rules and Strategies under Externalities and Uncertainties. — Helsinki: The Research Institute of the Finnish Economy, 2015. - 29 p.

${ }_{25}$ Bénassy-Quéré A. Short-Term Fiscal spillovers in a Monetary Union // CEPII Working Paper No. 2006-13. Paris: Centre D'Etudes Prospectives Et D'Informations Internationales, 2006. — 24 p. 
are mostly negative. However, income abroad may increase if taxes are reduced if lower prices completely offset the effects of higher interest rates. The response to the negative shock from the aggregate supply makes problems. Under such conditions, accelerating inflation requires an increase in interest rates, which will limit both aggregate supply and demand (due to a capital decrease). Insufficient price flexibility increases the value of the fiscal multiplier for the initiating country, but at the same time, the external effect weakens.

S. Gomez, P. Jacquinot and M. Pisani studied the external effects of fiscal incentives by DSGE adjusting of EAGLE model (Eurozone (Euro Area) and the Global Economy) model, which has four blocks - Germany, the rest of the EU countries, the United States and the rest of the world ${ }^{26}$. Accelerating effect from increase in government expenditures and tax cuts is bigger when fiscal promotion program is stated to be completed.

Even a brief glance of the external effects of fiscal policy of the most popular models of the open economy suggests that there is not a major trend to explain the effects of fiscal stimulus or fiscal austerity. Much depends on changes in the budget balance, as well as on the pattern of government expenditures and budget revenues and related circumstances (the method of financing the budget deficit, monetary policy support, etc.). The exchange rate practice has its own area of influence.

Normally, empirical evidence is not in favour of fiscal austerity policy as a factor of economic growth abroad. For example, using several macroeconomic models (QUEST-II, NiGEM, Marmotte, MULTIMOD Mark) D. Gros and A. Hobza found that an increase in government expenditures in Germany by $1 \%$ of GDP introduces positive external effects within $0.025 \%$ (Ireland ) $-0.22 \%$ (Belgium), but there is a slight negative impact (Italy, Spain, France, Portugal) ${ }^{27}$. According to recent IMF calculations, the increase in government expenditures in Germany can be expected to increase GDP in the Eurozone by a maximum of $0.2 \% 28$. The ECB's macroeconomic models show that reducing the budget deficit in Germany by $1 \%$ of GDP introduces an increase in GDP abroad of only $0.03 \%$ (France) and $0.06 \%$ for smaller countries on the European frontier area. QUEST-II model of the European Commission shows that an increase in public investment in Germany by $1 \%$ of GDP increases the GDP of the Eurozone by $0.2-0.3 \%$ (this is not a lot more).

In general, large-scale macroeconomic models do not support a significant impact abroad from fiscal shocks of individual countries, which

\footnotetext{
26 Gomes S., Jacquinot P., Pisani M. The EAGLE. A Model for Policy Analysis of Macroeconomic Interdependence in the Euro Area // ECB Working Paper Series No. 1195. — Frankfurt: European Central Bank, 2010. — 94 p.

27 Gros D., Hobza A. Fiscal policy spillovers in the Euro Area: Where are they? // CEPS Working Document No.176. - Brussels: Centre for European Policy Studies, 2001. -29 p.

${ }_{28}$ Poghosyan T. Cross-Country Spillovers of Fiscal Consolidations in the Euro Area // IMF Working Paper No. WP/17/140. — Washington: International Monetary Fund, 2017. - 37 p.
} 
contradicts the actual trends of the global financial crisis within 20082009, which confirmed the importance of external effects from macroeconomic shocks of individual countries (USA). One of the reasons is the lack of consideration of financial market relationships ${ }^{29}$. For example, the NiGEM model assumes that $1 \%$ increase in US government bond yields reduces GDP dynamic pattern by 0.5 percentage points in NAFTA countries, and in other countries - only by 0.1 percentage points. Similar estimates are actual for European countries ${ }^{30}$.

Econometric estimates have more remarkable external effects. In particular, a significant accelerating effect for trading partners resulted from the budget deficit in Germany, government expenditures in the five largest EU countries and the Eurozone in general ${ }^{31}$. Some studies say the external effects of the budget deficit in Germany are mostly positive, but not for all countries ${ }^{32}$. A. Ivanova and S. Weber found that small open European countries (Austria, Belgium, Ireland) are more vulnerable to the negative consequences of post-crisis improvement of the budget balance in countries such as Germany or France, but this does not happen in larger countries $^{33}$. This conclusion does not contradict the results of $\mathrm{R}$. Beetsma and M. Giuliodori that the economy openness significantly weakens the impact of fiscal incentives due to stronger external effects (this applies to both income in general and its individual components - private consumption and investment) ${ }^{34}$. At the same time, European Commission experts received an accelerating effect for the rest of the Eurozone countries from the improvement of the budget balance in Germany, but the result was weaker than for the fiscal austerity policy in France ${ }^{35}$. Estimates for the Eurozone generally show that the budget surplus has an expansionary

29 Bayomi T., Vitek F. Macroeconomic Model Spillovers and Their Discontents // IMF Working Paper No. WP/13/4. - Washington: International Monetary Fund, 2013. - $24 \mathrm{p}$.

Carreras O., Kirby S., Liadze I., Piggott R. Fiscal policy spillovers // NIESR Discussion Paper No. 468. London: National Institute of Economic and Social Research, 2016. -59 p.

31 Beetsma R., Giuliodori M., Klaassen F. Trade Spillovers of Fiscal Policy in the European Union: A Panel Analysis // Economic Policy. - 2006. - Vol. 21. - No. 48. - P. 640-687; Beetsma R., Giuliodori M. Discretionary fiscal policy: Review and estimates for the EU // The Economic Journal. - 2011. - Vol. 121. - No. 1. - P. F4-F32; Blanchard O., Erceg C., Lindé J. Jump-Starting the Euro Area Recovery: Would a Rise in Core Fiscal Spending help the Periphery? // Working Paper Series No. 304. - Stockholm: Sveriges Riksbank, 2015. — 82 p.; Ricci-Risquete A., Ramajo-Hernández J. Macroeconomic effects of fiscal policy in the European Union: a GVAR model // Empirical Economics. - 2015. - Vol. 48. - No. 4. - P. 1587-1617.

32 Bénassy-Quéré A., Cimadomo J. Changing Patterns of Domestic and Cross-Border Fiscal Policy Multipliers in Europe and the US // CEPII Working Paper No. 2006-24. — Paris: Centre D'Etudes Prospectives Et D'Informations Internationales, 2006. - 63 p.; Hebous S., Zimmermann T. Estimating the Effects of Coordinated Fiscal Actions in the Euro Area // European Economic Review. - 2013. - Vol. 58. - No. 2. - P. 110-121.

33 Ivanova A., Weber S. Do Fiscal Spillovers Matter? // IMF Working Paper No. WP/11/211. — Washington: International Monetary Fund, 2011. - 43 p.

34 Beetsma R., Giuliodori M. Discretionary fiscal policy: Review and estimates for the EU // The Economic Journal. - 2011. - Vol. 121. - No. 1. - P. F4-F32.

${ }_{35}$ Weyerstrass K., Jaenicke J., Neck R., Haber H., van Aarle B., Schoors K., Gobbin N., Claeys P. Economic spillover and policy coordination in the Euro Area // Economic Papers No. 246. — Brussels: European Commission, 2006. $-289 \mathrm{p}$ 
effect and improves the current account balance, mainly due to the favourable price effect.

Similarly, J. Hollmayr found that a $1 \%$ GDP increase in government expenditures in Germany reduces the GDP of trading partners by 0.4$0.8 \%{ }^{36}$. This contradicts the logic of the Mandel-Fleming model, but can be explained by the peculiarities of neoclassical and neo-Keynesian models ${ }^{37}$. The negative external effect obtained from the increase in government expenditures in Germany is explained by the predominance of the interest rate over the effects of foreign trade - price and income, as well as the low share of imports in such expenditures $(11 \%)$.

The ECB's NMCM model for European countries suggests that the fiscal consolidation within 2010-2013 had significant restrictive effects ${ }^{38}$. In another study, the losses of European countries' GDP from fiscal austerity policies are estimated at $4.3 \%$ in $2011,6.4 \%$ in 2012 and $7.7 \%$ in $2013^{39}$.

Numerous studies confirm the greater effectiveness of fiscal incentives under a fixed exchange rate ${ }^{40}$, as suggested by the Mandel-Fleming model. However, A. Auerbach and J. Gorodnichenko obtained quite the opposite conclusions: the external effects of fiscal policy were stronger for countries with a floating exchange rate ${ }^{41}$. T. Poghosyan's research confirms the increase in the external effects of fiscal policy during the recession, as well as in the monetary union ${ }^{42}$. Germany and France introduce the biggest external effects.

In course of fiscal consolidation programs, the opposite effects of such a restrictive fiscal policy may be explained by differences in the degree of confidence to such programs ${ }^{43}$. If confidence is high, we can hope for a reduction in the risk premium and cheaper credit resources, which becomes a factor in the recovery of aggregate demand. The weakness of the price effect compared to the interest rate effect explains the inverse relationship

\footnotetext{
36 Hollmayr J. Fiscal spillovers and monetary policy transmission in the Euro Area. — Frankfurt am Main: Goethe University Frankfurt am Main, 2012. - 61 p.

37 Corsetti G., Meier A., Müller G. What determines government spending multipliers // Economic Policy. 2012. - Vol. 27. - No. 72. - P. 521-565; Erceg C., Lindé J. Fiscal consolidation in a currency union: spending cuts vs. tax hikes // Journal of Economic Dynamics \& Control. — 2013. - Vol. 37. — No. 2. — P. $422-446$.

38 Attinasi M.-G., Lalik M., Vetlov I. Fiscal spillovers in the Euro Area a model-based analysis // ECB Working Paper No. 2040. - Frankfurt: European Central Bank, 2017. - 29 p. Gechert S., Hallett A. H., Rannenberg A. Fiscal multipliers in downturns and the effects of Eurozone consolidation // CEPR Policy Insight. -2015 . - 6 p.

40 Beetsma R., Giuliodori M. Discretionary fiscal policy: Review and estimates for the EU // The Economic Journal. - 2011. - Vol. 121. - No. 1. - P. F4-F32; Born B., Juessen B., Müller G. J. Exchange rate regimes and fiscal multipliers // Journal of Economic Dynamics and Control. - 2013. - Vol. 37. — No. 2. - P. 446-465; Ilzetzki E., Mendoza E., Végh C. How big (small?) are fiscal multipliers? // Journal of Monetary Economics. - 2013. Vol. 60. - No. 2. - P. 239-254

41 Auerbach A. J., Gorodnichenko Y. Output spillovers from fiscal policy // American Economic Review. - 2013. - Vol. 103. - No. 3. - P. 141-146.

${ }^{42}$ Poghosyan T. Cross-Country Spillovers of Fiscal Consolidations in the Euro Area // IMF Working Paper No. WP/17/140. - Washington: International Monetary Fund, 2017. - $37 \mathrm{p}$

${ }^{43}$ Beetsma R., Cimadomo J.. Furtuna O.. Giuliodori M. The confidence effects of fiscal consolidations // Economic Policy. - 2015. - Vol. 30. — No. 83. - P. 439-489.
} 
ASYMMETRY OF EXTERNAL EFFECTS OF THE BUDGET BALANCE OF THE LARGEST EUROZONE COUNTRIES AS AN OBSTACLE TO FISCAL POLICY COORDINATION

between government expenditures in Germany and economic growth $\operatorname{abroad}^{44}$.

The results on the impact of fiscal policy on price ratios in foreign trade do not show a dominant relationship, but most studies say about RER increase in response to increasing budget deficits, such as R. Beetsma and M. Giuliodori ${ }^{45}$, which corresponds to the Mandel-Fleming model. In this case, the fiscal austerity policy should be accompanied by RER increase in countries of the European frontier area.

In general, the empirical results of the external effects of fiscal policy for European countries mainly show the expansionary impact of fiscal incentives, but the results for individual countries may differ. Normally, the interest rate policy looks weaker than the policy income and relative prices, but we should underline the importance of capital movements, which can offset the effects of foreign trade. The hypothesis of greater efficiency of government expenditures compared to tax cuts does not look as significant as in studies for individual countries. The external effects of fiscal policy are more noticeable under conditions of a fixed exchange rate. It is clear that significant external effects strengthen the reasons of fiscal policy coordination. This is particularly true of changes in the budget balances of the largest countries, such as Germany, France, Italy or the Netherlands, or the Eurozone as a whole, have an asymmetric impact on individual countries on the European frontier area.

\section{Research methods}

As shown above, the macroeconomic effects of fiscal policy may depend on the instruments chosen, the framework features of individual countries, the expectations of market participants and institutional changes (within an integration force, these may be attempts to adjust economic policy). In our opinion, it is methodologically necessary to consider the intertemporal nature of fiscal shocks and the need to verify the results obtained for sustainability. An option of changing the direction of fiscal shock over time suggests the use of the method of Vector Auto-Regression (VAR), which supports tracking the impact of fiscal shocks in time.

The VAR model for studying the external effects of Eurozone fiscal policy and its two largest countries (Germany, France) contains three variables: budget balance (\% of GDP), $B D_{t}$, actual exchange rate (index, $2010=100), R E R_{t}$, cyclical GDP dynamics (\%), $Y C_{t}$. Cyclical developments

${ }^{44}$ Hollmayr J. Fiscal spillovers and monetary policy transmission in the Euro Area. — Frankfurt am Main: Goethe University Frankfurt am Main, 2012. - $61 \mathrm{p}$.

${ }_{45}$ Beetsma R., Giuliodori M. Discretionary fiscal policy: Review and estimates for the EU // The Economic Journal. — 2011. - Vol. 121. — No. 1. - P. F4-F32. 
in GDP were measured in deviations from the equilibrium trend (\%), which was obtained using Hodrick-Prescott filter. This is practiced in most studies, although other indicators can be used instead of the cyclical dynamics of GDP: the "natural" or actual value of GDP or its individual components, i.e. investment and private consumption ${ }^{46}$. A significant advantage of using the indicator of GDP cyclical dynamics is its stationarity for all studied countries (Poland, Romania, Czech Republic, Hungary, Bulgaria, Slovakia, Slovenia, Greece, Spain, Portugal), which is confirmed by Augmented Dickey-Fuller Test and the Phillips-Perron Test. Since RER turned out to be a non-stationary indicator, it was used as the first differences of the relevant logarithms. The stationarity of all three indicators ensures the use of the canonical VAR model without error correction.

Taking the vector of dependent (endogenous) variables $t$ of dimension $k$, in the given form the VAR model can be written as follows:

$$
\mathbf{X}_{t}=C+A(L) \mathbf{X}_{t-1}+\mathbf{D}_{t}+u_{t}
$$

where $C$ contains deterministic components (constant and linear trend), $A$ (L) - matrix polynomial with lag operator $L, \mathbf{D}_{t}$, - vector of independent (exogenous) variables, $u_{t}$ - vector of $k \times 1$ dimension of balances that are normally distributed $\mathrm{E}\left[u_{t}\right]=0$ and characterized by a constant covariance matrix, $\mathrm{E}\left[u_{t} u_{t}^{\prime}\right]=\Sigma_{u}$, where $\mathrm{E}\left[u_{t} u_{s}^{\prime}\right]=0$ for $s \neq t$.

The vector of dependent variables chosen by us is $\mathbf{X}_{t}=\left[B D_{t}, \Delta \ln R E R_{t}, Y C_{t}\right]$. It is assumed that in the current period, the budget balance of the Eurozone affects the changes in RER; this becomes a factor in changes in income. Accordingly, the business cycle depends on income abroad, which directly depends on the budget balance of the country initiating the fiscal shock, and the dynamics of relative prices as two tools for implementing the external effects of fiscal policy in the Eurozone. At the same time, the tools of capital flows and risk premiums are behind the scene, but it can be assumed that changes in RER partially consider both factors. If we use an extended VAR model with 5-6 variables, the quality of the estimates may suffer from insufficient observations (data on the budget balance of the Eurozone countries are available since 2002); for CEE countries the issue will be further complicated by increased volatility of capital flows in economies with insufficient developed financial markets. In this condition, using a compact VAR model with three variables looks like a reliable compromise. In general, the study can be considered a starting point for more detailed

\footnotetext{
46 Hebous S., Zimmermann T. Estimating the Effects of Coordinated Fiscal Actions in the Euro Area // European Economic Review. — 2013. - Vol. 58. - No. 2. - P. 110-121.
} 
research of the dependence of European frontier countries on the fiscal policy of the largest European countries, which will compare the results for different specifications of the VAR model.

\section{The results obtained}

Empirical results based on the VAR model in terms of the impact of the budget surplus of the largest European countries on RER and the cyclical position of GDP of European frontier countries are presented in Fig. 1 and 2. The first differences of the RER logarithm are shown on the vertical coordinate axis, while changes in GDP are measured in deviations from the equilibrium trend (\%). Units of time (quarter) are given on the horizontal axis. For some countries, VAR models were used with two (Slovakia, Slovenia), three (Bulgaria, Poland, Romania, Hungary, Czech Republic), five (Greece, Portugal) or six lags (Spain), which meets the Schwarz information criterion (SC) and Hannan-Quinn information criterion (HQ). In all cases, the stationary balances introduce no problems with the specification of VAR models.

In the CEE countries, the resulting increase in RER, which is in line with the logic of the Mandel-Fleming model, is very marked in case of an improvement in the budget balance of the Eurozone countries (Fig. 1). For countries with a floating exchange rate, this effect is short-term, and for countries with a fixed exchange rate, it is quite a long-term effect. The feedback of relative prices to changes in the budget balance of the Eurozone countries is much weaker in the countries of Southern Europe (only in Spain there is a decrease in RER). The improvement in the budget balances in Germany and France is depicted in the short-term increase in RER in CEE countries with floating exchange rate, while for CEE countries with a fixed exchange rate the impact on RER is quite diverse. The same trends are applied to the countries of Southern Europe.

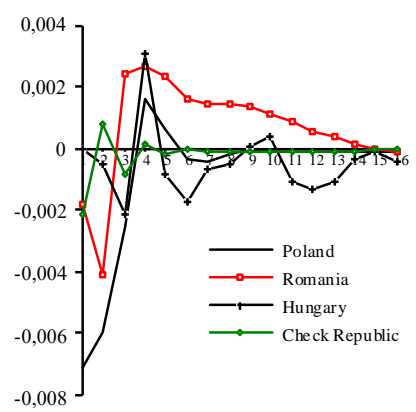

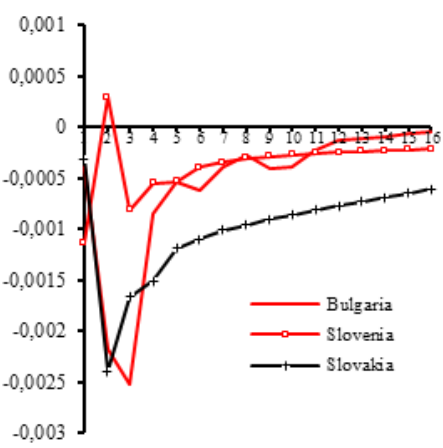

a) Eurozone

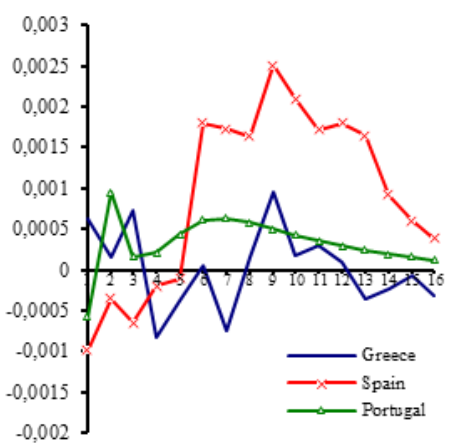



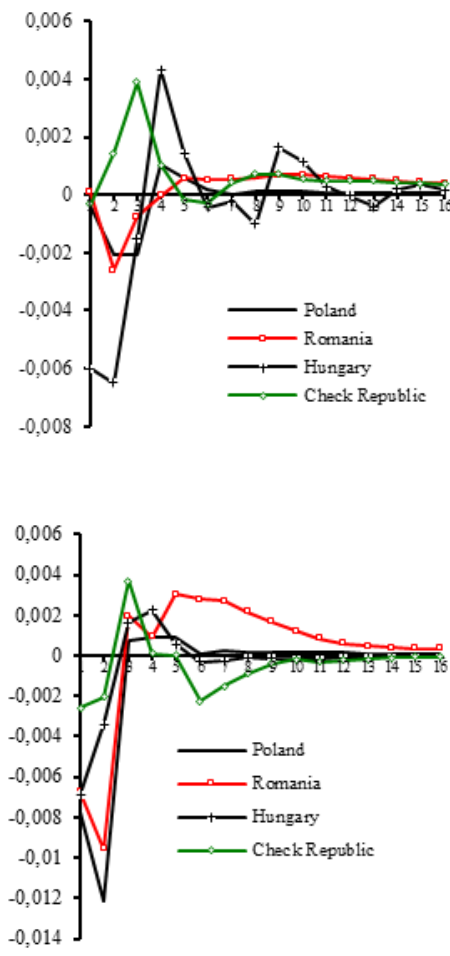

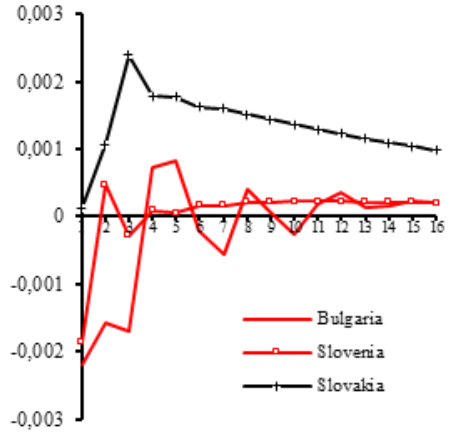

b) Germany
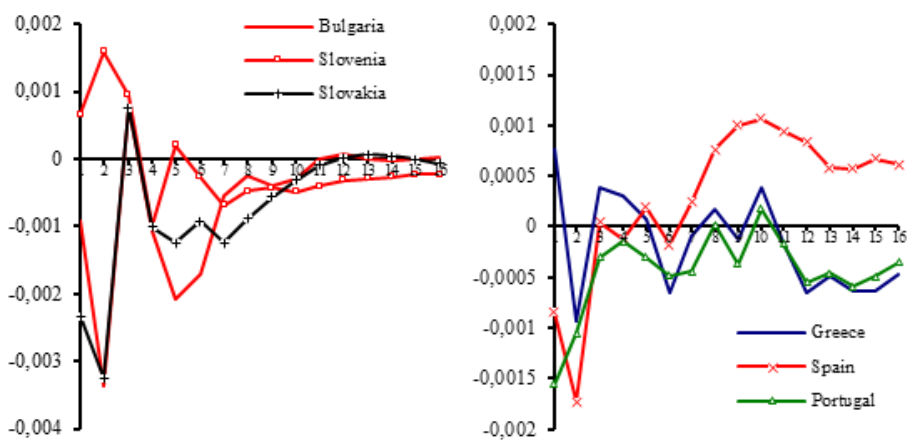

c) France

Fig. 1. The impact of the budget balance of the largest European countries on RER ${ }^{47}$.

The impact on GDP dynamics looks much more stable for certain groups of countries. CEE countries have a clear incentive effect from fiscal austerity policies. Improving the budget balance of the Eurozone countries by $1 \%$ of GDP increases the GDP growth rate of Bulgaria, Slovenia and Slovakia within 0.3-0.4 percentage points. In Hungary, the accelerating effect reaches 0.6 percentage points, and in Romania - 0.4 percentage points, but in Poland and the Czech Republic - does not exceed 0.2 percentage points. On the other hand, the opposite effect was obtained for the countries of Southern Europe, where within a lag of 3-4 quarters there is a very significant restrictive effect. In Greece, the improvement in the Eurozone budget balance by $1 \%$ of GDP can be expected to reduce GDP by 0.6 percentage points, but after about two years, the restrictive effect disappears. In Spain and Portugal, the decline in production yield is less deep, but longer in time. It is telling that the restrictive effect of fiscal savings in Germany is less than the reduction of the budget deficit in

\footnotetext{
${ }^{47}$ Developed by the authors.
} 
ASYMMETRY OF EXTERNAL EFFECTS OF THE BUDGET BALANCE OF THE LARGEST EUROZONE COUNTRIES AS AN OBSTACLE TO FISCAL POLICY COORDINATION

France. Thus, the asymmetry of the impact of fiscal austerity policy on the countries of the European frontier area is very significant.
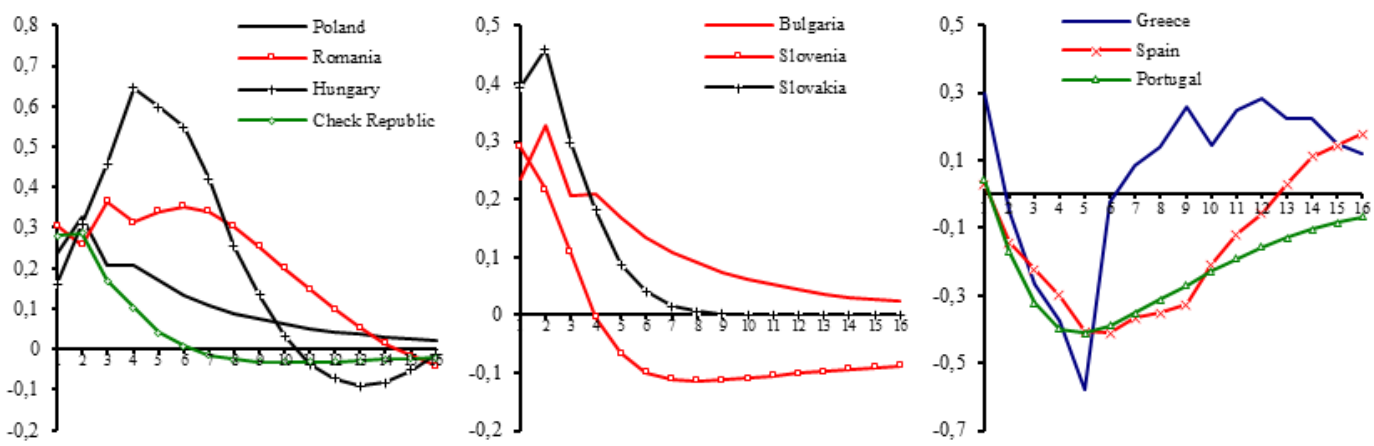

a) Eurozone
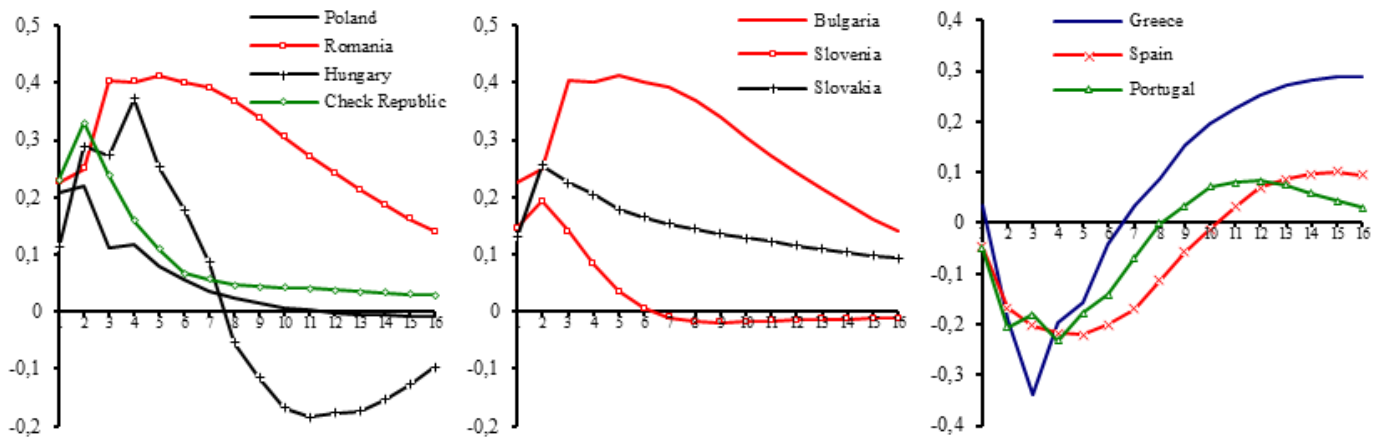

b) Germany
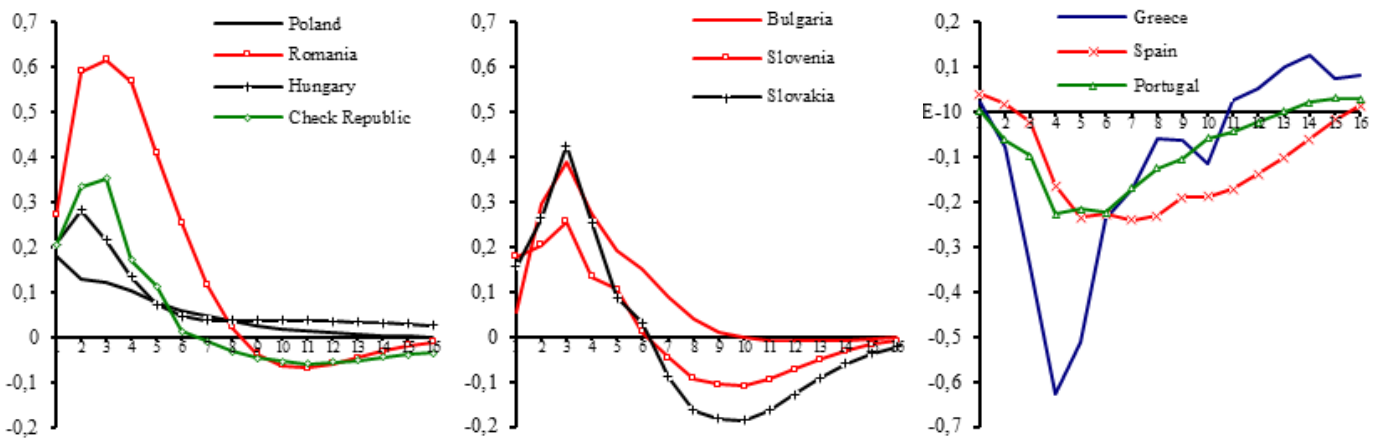

c) France

Fig. 2. The impact of the budget balance of the largest European countries on GDP 48

${ }^{48}$ Developed by the authors. 
Decomposition of balances of the VAR model reveals a greater dependence of cyclical changes in GDP on the budget balance of the Eurozone countries than Germany or France (except for the Czech Republic) (Table 1). Unexpectedly, the importance of external effects from the German budget balance is significantly higher than in France in three countries (Poland, Romania and Bulgaria). The external effects of European budget balances account for more than $40 \%$ of $Y C_{t}$ changes in Hungary, over $30 \%$ in Bulgaria, Spain and Portugal, and over $20 \%$ in Romania and Greece. The importance of external effects of European fiscal policy is lower in the Czech Republic, Slovakia and Slovenia.

Table 1

DECOMPOSITION OF BALANCES ON THE EXTERNAL EFFECTS OF THE BUDGET BALANCE OF THE LARGEST EUROZONE COUNTRIES ${ }^{49}$

\begin{tabular}{|c|c|c|c|c|c|c|c|c|c|c|c|c|}
\hline \multirow{3}{*}{ Country } & \multicolumn{4}{|c|}{ Eurozone } & \multicolumn{4}{|c|}{ Germany } & \multicolumn{4}{|c|}{ France } \\
\hline & \multicolumn{4}{|c|}{ Forecasting time-frame } & \multicolumn{4}{|c|}{ Forecasting time-frame } & \multicolumn{4}{|c|}{ Forecasting time-frame } \\
\hline & 2 & 4 & 8 & 12 & 2 & 4 & 8 & 12 & 2 & 4 & 8 & 12 \\
\hline \multicolumn{13}{|c|}{ CEE countries with floating exchange rate } \\
\hline Poland & 8 & 19 & 21 & 21 & 10 & 9 & 9 & 9 & 4 & 4 & 4 & 4 \\
\hline Romania & 7 & 12 & 21 & 20 & 4 & 10 & 20 & 24 & 2 & 2 & 9 & 15 \\
\hline Hungary & 10 & 32 & 49 & 44 & 6 & 10 & 11 & 13 & 22 & 28 & 31 & 31 \\
\hline $\begin{array}{l}\text { Check } \\
\text { Republic }\end{array}$ & 13 & 11 & 10 & 10 & 12 & 12 & 13 & 13 & 14 & 18 & 18 & 19 \\
\hline \multicolumn{13}{|c|}{ CEE countries with fixed exchange rate } \\
\hline Bulgaria- & 15 & 28 & 33 & 33 & 17 & 32 & 33 & 34 & 6 & 15 & 17 & 17 \\
\hline Slovakia & 14 & 15 & 15 & 15 & 3 & 6 & 9 & 11 & 1 & 12 & 13 & 16 \\
\hline Slovenia & 6 & 7 & 7 & 8 & 3 & 3 & 3 & 3 & 6 & 8 & 8 & 9 \\
\hline \multicolumn{9}{|c|}{ Countries of Southern Europe } & & & & \\
\hline Greece & 9 & 17 & 23 & 22 & 2 & 7 & 6 & 10 & 1 & 19 & 22 & 22 \\
\hline Spain & 7 & 23 & 39 & 32 & 7 & 14 & 18 & 18 & 1 & 5 & 18 & 22 \\
\hline Portugal & 4 & 23 & 25 & 36 & 7 & 10 & 12 & 12 & 1 & 4 & 11 & 11 \\
\hline
\end{tabular}

The obtained results testify to the absolute usefulness of fiscal austerity policy for CEE countries, which differs from negative assessments for other

${ }^{49}$ Developed by the authors. 
ASYMMETRY OF EXTERNAL EFFECTS OF THE BUDGET BALANCE OF THE LARGEST EUROZONE COUNTRIES AS AN OBSTACLE TO FISCAL POLICY COORDINATION

countries of the European frontier area ${ }^{50}$. This result for CEE countries may be affected by capital outflows due to interest rate differences or reduced risk against a weak price effect ${ }^{51}$. If we consider the countries of the European frontier area in general, the previous results confirm that the budget deficit in Germany affects individual countries in different ways ${ }^{52}$. On the other hand, this trend is not specific for the countries with similar regional features.

Assessing the possible practice of the favourable impact of fiscal austerity policy, it is most likely resulted from reduced profitability of entrepreneurial activity in the initiating country - Germany or France, which leads to the transfer of activities to CEE countries to reduce production costs. Assuming an immediate increase in aggregate supply after foreign capital inflows, such an effect can be obtained using the AD-AS textbook model. It is clear that the investment attractiveness of CEE countries will be enhanced by risk reduction, which is linked to fiscal savings in Germany or the Eurozone as a whole, as this facilitates the options of "rescuing" troubled economies of the European frontier area.

\section{Proposals for economic policy}

According to the analysis of the external effects of the budget balance of the largest EU countries, the best rule of fiscal policy is the following:

$$
B_{t}=\bar{B}+a_{1}\left(Y_{t}-\bar{Y}\right)+a_{2}\left(D_{t}-\bar{D}\right)+a_{3} C A_{t}+a_{4} B E U R O_{t} \text {, where } B_{t} \text { - budget }
$$

balance ( $\%$ of GDP), $\bar{B}$ - selected budget balance target ( \% of GDP), $Y_{t}-\bar{Y}$ - "gap" of GDP (difference between current and "natural" value), $D_{t}-\bar{D}$ - difference between actual and "threshold" level of public debt (\% of GDP), $C A_{t}$ - current account balance ( $\%$ of GDP), BEURO budget balance of the largest Eurozone countries ( $\%$ of GDP).

It is assumed that the estimated budget balance depends on the chosen target, the cyclical position of the economy (or "gap" in income), the size of public debt, current account balance and external effects of fiscal policy of the largest countries in the Eurozone.

The chosen target of the budget balance $\bar{B}$ may depend on the conditions of a particular country, in particular the level of public debt. For example, the balanced budget rule of the EU countries, which

50 Beetsma R., Giuliodori M., Klaassen F. Trade Spillovers of Fiscal Policy in the European Union: A Panel Analysis // Economic Policy. - 2006. - Vol. 21. - No. 48. - P. 640-687; Beetsma R., Giuliodori M. Discretionary fiscal policy: Review and estimates for the EU // The Economic Journal. — 2011. - Vol. 121. - No. 1. - P. F4-F32.

${ }^{51}$ Hollmayr J. Fiscal spillovers and monetary policy transmission in the Euro Area. — Frankfurt am Main: Goethe University Frankfurt am Main, 2012. - 61 p.

${ }_{52}$ Crespo-Cuaresma J., Eller M., Mehrotra A. The Economic Transmission of Fiscal Policy Shocks from Western to Eastern Europe // Focus on European Economic Integration. - 2011. - No. 2. — P. 44-68. 
appeared in 2012 in connection with the Fiscal Contract, supports an annual target of structural deficit budget of at least $0.5 \%$ of GDP, but for countries with low levels of external debt (well below $60 \%$ of GDP) the lower limit may be at $1 \%$ of GDP ${ }^{53}$. Deviations from these guidelines were accepted in exceptional cases. Compliance with this rule will be monitored by the European Court of Justice, which will be able to impose fines of up to $0.1 \%$ of the country's GDP paid to the European Financial Stability Facility for Eurozone member states and the EU budget in other cases.

The fiscal policy countercyclical action desirable for the income function implies a direct dependence of the budget balance on the "gap" of income $\left(a_{1}>0\right)$. The key problem is the method of identifying the cyclic position. Normally, the "gap" of income is obtained by filtering Hodrick-Prescott or Kalman. This technique does not cause problems during a stable route of economic growth, but may introduce some difficulties in case of a transition to a new equilibrium trend, as happened during the global financial crisis of 2008-2009. For example, a sharp decline in the equilibrium trend in the US exceeded the pre-crisis economic boom, while the cyclical decline in production yield during the "great recession" was smaller.

In terms of compliance with fiscal sustainability, it is necessary to respond to the increase in public debt above a certain "threshold" value; for the majority of EU countries, the respective value should be below $60 \%$ of GDP. This also implies a direct relationship between public debt and budget balance $\left(a_{2}>0\right)$. Empirical studies say that the response of the budget balance to the increase in public debt is significantly weak in case of a decline in government borrowing, accelerating inflation and a sudden decline in the equilibrium GDP growth rate ${ }^{54}$. This feature is expected to refer to weakening of fiscal sustainability. For most major economies, according to the pre-crisis period, it is true that the response of the budget balance to the increase in public debt generally corresponds to the logic of intertemporal budgetary constraints. It also confirms the stationary indicator of public debt, which normally serves as a landmark of fiscal sustainability. However, for some countries, the logic of the time constraint is lost with the inclusion of data after 2008. This means that the global financial crisis of 2008-2009 and the relevant fiscal incentives have significantly worsened fiscal sustainability.

Finally, the dependence on the budget balances of the Eurozone countries is specific to each country $\left(a_{4}<>0\right)$. If for the countries of Southern Europe the improvement of the budget balance abroad has a

53 Razumkov Center. Reformatting European integration: opportunities and risks for the Ukraine-EU association. Kyiv: Razumkov Center, 2018. - 213 p. [In Ukrainian].

${ }_{54}$ Mauro P., Romeu R., Binder R., Zaman A. A modern history of fiscal prudence and profligacy // Journal of Monetary Economics. — 2015. - Vol. 76. - No. 1. - P. 55-70. 
restrictive effect, i.e. it is necessary to response asymmetrically by increasing the budget deficit $\left(a_{4}<0\right)$, assuming the standard Keynesian income dependence on budget balance. In this case, it is actually an issue of elimination of a part of the external effect of the fiscal policy of the Eurozone countries. At the same time, for CEE countries, the symbol changes to the opposite $\left(a_{4}>0\right)$, as the improvement of the budget balance in Germany has an expansionary impact.

\section{Conclusions}

Summarizing the results obtained and proposals made, the fiscal policy of individual European countries should consider both the domestic economic situation and the external effects of fiscal policy of major European countries, such as Germany and France. The asymmetry of such external effects is expected to question the coordination of fiscal policy. According to quarterly data within 2002-2019, the budget surpluses of Germany and France and the Eurozone in general improve the cyclical position of GDP in CEE countries (the relevant accelerating effect is observed regardless of the exchange rate patterns), while a strong restrictive effect is obtained for Southern Europe. However, such an adverse effect is mostly a short-term trend; for Spain, the long-term accelerating effect remains possible. The obtained results mean that the fiscal austerity policy of Germany within 2010-2013 deepened the slump in production in the countries of Southern Europe, but was favourable for the CEE countries.

The identified features of external effects of fiscal policy of the largest Eurozone countries are the reasons in favour of the use of fiscal policy rules that consider both cyclical position of the economy, achieved public debt or current account balance, and the nature of external effects of fiscal policy of the largest Eurozone countries. In general, fiscal policy rules for individual countries can be a convenient complement to institutional constraints such as the Maastricht criteria on budget balance and public debt, as well as targeted institutions such as fiscal policy councils aimed at consolidating the countercyclical nature of fiscal instruments.

\section{References}

1. Acocella, N., Di Bartolomeo, G., and P. Tirelli. 2007. "Monetary conservatism and fiscal coordination in a monetary union." Economics Letters 94 (1): 56-63. https: / / doi.org/10.1016/ j.econlet.2006.08.002

2. Alcidi, C., Мддttдnen, N., and G. Thirion. 2015. "Cross-Country Spillover Effects and Fiscal Policy Coordination in EMU." FIRSTRUN - Fiscal Rules 
and strategies under Externalities and Uncertainties. Helsinki: The Research Institute of the Finnish Economy.

3. Allard, C., Brooks, P. K., Bluedorn, J. C., Bornhorst, F., Christopherson, K., Ohnsorge, F., and T. Poghosyan. 2013. "Toward a Fiscal Union for the Euro Area." IMF Staff Discussion Note No. 13/09. Washington: IMF.

4. Attinasi, M.-G., Lalik, M., and I. Vetlov. 2017. "Fiscal spillovers in the Euro Area a model-based analysis." ECB Working Paper No. 2040. Frankfurt: European Central Bank.

5. Auerbach, A. 2014. "Budget Rules and Fiscal Policy: Ten Lessons from Theory and Evidence." German Economic Review 15 (1): 84-99. https://doi.org/10.1111/geer.12023.

6. Auerbach, A. J., and Y. Gorodnichenko. 2013. "Output spillovers from fiscal policy." American Economic Review, 103 (3): 141-146. https: / / doi.org/10.1257/aer.103.3.141

7. Barbier-Gauchard, A., Betti, T., and G. Diana. 2015. "Spillover effects in a monetary union: Why fiscal policy instruments matter." Working Paper No. 201501. Strasbourg: Universitŭ de Strasbourg.

8. Baxter, M. 1995. "International trade and business cycles." In Handbook of International Economics, edited by G. M. Grossman and K. Rogoff, 1801-1868. Amsterdam: North-Holland.

9. Bayomi, T., and F. Vitek. 2013. "Macroeconomic Model Spillovers and Their Discontents." IMF Working Paper No. WP/13/4. Washington: International Monetary Fund.

10. Beetsma, R., Debrun, $X$., and F. Klaassen. 2001. "Is Fiscal Policy Coordination in EMU Desirable?" IMF Working Paper No. WP/01/178. Washington: International Monetary Fund.

11. Beetsma, R., Giuliodori, M., and F. Klaassen. 2006. "Trade Spillovers of Fiscal Policy in the European Union: A Panel Analysis." Economic Policy, 21 (48): 640-687. https: / / doi.org/10.1111/ j.1468-0327.2006.00168.x

12. Beetsma, R., and M. Giuliodori. 2011. "Discretionary fiscal policy: Review and estimates for the EU." The Economic Journal, 121 (1): F4-F32. https: / / doi.org/10.1111/j.1468-0297.2010.02412.x.

13. Beetsma, R., Cimadomo, J., Furtuna, O., and M. Giuliodori. 2015. "The confidence effects of fiscal consolidations." Economic Policy, 30 (83): 439-489. https: / / doi.org / 10.1093/epolic/eiv007.

14. Begg, I., Hodson, D., and I. Maher. 2003. "Economic policy coordination in the European Union." National Institute Economic Review, 183 (1): 66-77. https: / / doi.org / 10.1177/ 0027950103183001462.

15. Belke, A., and D. Gros. 2009. "On the benefits of fiscal policy coordination in a currency union: a note." Empirica, 36 (1): 45-49. https: / / doi.org/10.1007/s10663-008-9091-2.

16. Вйnassy-Quйгй, A. 2006. "Short-Term Fiscal Spillovers in a Monetary Union." CEPII Working Paper No. 2006-13. Paris: Centre D'Etudes Prospectives Et D'Informations Internationales.

17. Вйnassy-Quйrй, A., and J. Cimadomo. 2006. "Changing Patterns of Domestic and Cross-Border Fiscal Policy Multipliers in Europe and the US." 
ASYMMETRY OF EXTERNAL EFFECTS OF THE BUDGET BALANCE OF THE LARGEST EUROZONE COUNTRIES AS AN OBSTACLE TO FISCAL POLICY COORDINATION

CEPII Working Paper No. 2006-24. Paris: Centre D’Etudes Prospectives Et D'Informations Internationales.

18. Blanchard, O., Erceg, C., and J. Lindü. 2015. "Jump-Starting the Euro Area Recovery: Would a Rise in Core Fiscal Spending help the Periphery?" Working Paper Series No. 304. Stockholm: Sveriges Riksbank.

19. Born, B., Juessen, B., and G. Mbller. 2013. "Exchange rate regimes and fiscal multipliers." Journal of Economic Dynamics and Control, 37 (2): 446-465. https: / / doi.org/10.1016/ j.jedc.2012.09.014

20. Canova, F., Ciccarelli, N., and P. Dallari. 2013. "Spillover of fiscal shocks in the Euro Area." Frankfurt: European Central Bank.

21. Canzoneri, M., Cumby, R., and B. Diba. 2005. "The need for international policy coordination: what's old, what's new, what's yet to come?" Journal of International Economics, 66 (2): 363-384. https://doi.org/10.1016/ j.jinteco.2004.03.005.

22. Carreras, O., Kirby, S., Liadze, I., and R. Piggott. 2016. "Fiscal policy spillovers." NIESR Discussion Paper No. 468. London: National Institute of Economic and Social Research.

23. Corsetti, G., and G. Mbller. 2008. "Twin deficits, openness and the business cycle." Journal of European Economic Association, 6 (2-3): 404-413. https: / /doi.org/10.1162/JEEA.2008.6.2-3.404.

24. Corsetti, G., Meier, A., and G. Mbller. 2010. "Cross-Border Spillovers from Fiscal Stimulus." International Journal of Central Banking, 6 (1): 5-37.

25. Corsetti, G., Meier, A., and G. Mbller G. 2012. "What determines government spending multipliers." Economic Policy, 27 (72): 521-565. https: / / doi.org/10.1111/j.1468-0327.2012.00295.x.

26. Crespo-Cuaresma, J., Eller, M., and A. Mehrotra. 2011. "The Economic Transmission of Fiscal Policy Shocks from Western to Eastern Europe." Focus on European Economic Integration, 2: 44-68.

27. Erceg, C., and J. Lindŭ. "Fiscal consolidation in a currency union: spending cuts vs. tax hikes." Journal of Economic Dynamics \& Control, 37 (2): 422-446. https://doi.org/10.1016/j.jedc.2012.09.012.

28. Gadatsch, N., Hauzenberger, K., and N. Stдhler. 2015. "German and the rest of Euro Area fiscal policy during the crisis." DB Discussion Paper No. $05 / 2015$. Frankfurt: Deutsche Bundesbank.

29. Gechert, S., Hallett, A. H., and A. Rannenberg. 2015. "Fiscal multipliers in downturns and the effects of Eurozone consolidation." CEPR Policy Insight.

30. Gomes, S., Jacquinot, P., and M. Pisani. 2010. "The EAGLE. A Model for Policy Analysis of Macroeconomic Interdependence in the Euro Area." ECB Working Paper Series No. 1195. Frankfurt: European Central Bank.

31. Gros, D., and A. Hobza. 2001. "Fiscal policy spillovers in the Euro Area: Where are they?" CEPS Working Document No.176. Brussels: Centre for European Policy Studies.

32. Hebous, S., and T. Zimmermann. 2013. "Estimating the Effects of Coordinated Fiscal Actions in the Euro Area." European Economic Review, 58 (2): 110-121. https://doi.org/10.1016/ j.euroecorev.2012.12.002. 
33. Hollmayr, J. 2012. "Fiscal spillovers and monetary policy transmission in the Euro Area." Frankfurt am Main: Goethe University Frankfurt am Main.

34. Ilzetzki, E., Mendoza, E., and C. Vügh. 2013. "How big (small?) are fiscal multipliers?" Journal of Monetary Economics, 60 (2): 239-254. https: / / doi.org / 10.1016/j.jmoneco.2012.10.011.

35. Ivanova, A., and S. Weber. 2011. "Do Fiscal Spillovers Matter?" IMF Working Paper No. WP $/ 11 / 211$. Washington: International Monetary Fund.

36. Lambertini, L., and R. Rovelli. 2002. "Optimal Fiscal Stabilization Policy with Credible Central Bank Independence." Quaderni-Working Paper DSE No. 460. Bologna: Universita' di Bologna.

37. Mauro, P., Romeu, R., Binder, R., and A. Zaman. 2015. "A modern history of fiscal prudence and profligacy." Journal of Monetary Economics, 76 (1): 55-70. https: / / doi.org/10.1016/ j.jmoneco.2015.07.003.

38. Obstfeld, M., and K. Rogoff. 1995. "Exchange Rate Dynamics Redux." Journal of Political Economy, 103 (3): 624-660. https://doi.org/10.1086/ 261997.

39. Poghosyan, T. 2017. "Cross-Country Spillovers of Fiscal Consolidations in the Euro Area." IMF Working Paper No. WP/17/140. Washington: International Monetary Fund.

40. Razumkov Center. Reformatting European integration: opportunities and risks for the Ukraine-EU association. Kyiv: Razumkov Center, 2018. - 213 p. URL: https://razumkov.org.ua/uploads / article / 2018_pereformatuvannia_ ievropeiskoi_intehratsii.pdf [In Ukrainian].

41. Ricci-Risquete, A., and J. Ramajo-Hernondez. "Macroeconomic effects of fiscal policy in the European Union: a GVAR model." Empirical Economics, 48 (4): 1587-1617. https://doi.org/10.1007/ s00181-014-0843-5.

42. Sadeh, T. 2019. "How did the Euro Area survive the crisis?" West European Politics, 42 (1): 201-226. https://doi.org/10.1080/ 01402382.2018 .1466478$.

43. Veld, J. "Fiscal Consolidations and Spillovers in the Euro Area Periphery and Core" EC Economic Papers No. 506. Brussels: European Commission, 2013.

44. Weyerstrass, K., Jaenicke, J., Neck, R., Haber, H., van Aarle, B., Schoors, K., Gobbin, N., and P. Claeys. 2006. "Economic spillover and policy coordination in the Euro Area" Economic Papers No. 246. Brussels: European Commission.

45. Wyplosz, C. 2016. "The six flaws of the Eurozone" Economic Policy, 31 (87): 559-606. https://doi.org/10.1093/epolic/eiw008.

The article was received by the Editorial Board on March 17, 2021. 